\title{
TREATMENT WITH HYDROXYCHLOROQUINE IN PATIENTS WITH COVID-19. EXPERIENCE OF A NEUROLOGY DEPARTMENT
}

\author{
EUGENIA IRENE DAVIDESCU ${ }^{1,2 *}$, IRINA ODAJIU ${ }^{1}$, TEODORA BUNEA ${ }^{1}$, GEORGIANA \\ SANDU $^{1}$, LAURENȚIU STRATAN ${ }^{2,4}$, VICTORIA ARAMĂ ${ }^{2,4}$, BOGDAN OVIDIU POPESCU ${ }^{1,2,3}$

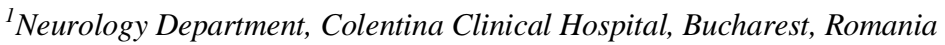 \\ 2 "Carol Davila” University of Medicine and Pharmacy, Bucharest, Romania \\ ${ }^{3}$ Laboratory of Cell Biology, Neurosciences and Experimental Myology, "Victor Babeș” National Institute of Pathology, \\ Bucharest, Romania \\ 4 "Matei Balș” National Institute of Infectious Diseases, Bucharest, Romania
}

*corresponding author: eugenia.davidescu@umfcd.ro

Manuscript received: April_2020

\begin{abstract}
The novel coronavirus has generated the Coronavirus Disease 2019 (COVID-19) pandemic, which has become the new challenge for the healthcare systems, since there is no etiological treatment and the infectiousness of SARS-CoV2 is exceeding the expectations. Therefore, various treatments have been tried in an attempt to stop the spread of the virus and to enhance the early recovery of the patients. Hydroxychloroquine, an antimalarial drug used for decades, has been one of the first drugs tried to reduce the infectivity of the virus. First data were promising, but afterwards, adverse events and long-term evolution of patients outweighed the potential benefits, and its utility was questioned. In this article we are reviewing literature regarding the use of Hydroxychloroquine during the COVID-19 pandemic and we present the experience of its use in the Neurology Department in Colentina Clinical Hospital, Bucharest, Romania.
\end{abstract}

\section{Rezumat}

Noul coronavirus a generat pandemia COVID-19, care a devenit noua provocare pentru sistemele de sănătate, din moment ce nu există tratament etiologic, iar contagiozitatea SARS-CoV2 depășește aşteptările. Prin urmare, s-au încercat diverse tratamente în încercarea de a opri răspândirea virusului și de a favoriza recuperarea precoce a pacienților. Hidroxiclorochina, un medicament antimalaric utilizat de zeci de ani, a fost unul dintre primele medicamente încercate să reducă infecțiozitatea virusului. Primele date au fost promițătoare, dar ulterior, evenimentele adverse și evoluția pe termen lung ale pacienților au depășit potențialele beneficii, iar utilitatea sa a fost pusă la îndoială. În acest articol analizăm literatura de specialitate privind utilizarea hidroxiclorochinei în timpul pandemiei COVID-19 și prezentăm experiența utilizării sale în secția de Neurologie din Spitalul Clinic Colentina, București, România.

Keywords: hydroxychloroquine, COVID-19, SARS-CoV2, treatment, pandemic

\section{Introduction}

Since the outbreak of the severe acute respiratory syndrome coronavirus 2 (SARS-CoV2) pandemic, officially declared by the World Health Organization (WHO) on the 11 of March 2020, with its original epicentre in Wuhan, in the Hubei province of China, announced by the local authorities on the 8 of December 2019, the medical community faces one of the greatest challenges. The novel betacoronavirus, which is claimed to have passed on from bats, is a one of the seven coronaviruses strains capable to induce disease in humans and the third highly pathogenic strain. This single-stranded positive-sense RNA virus belonging to the Coronaviridae family in the order Nidovirales [46] has gained its official name by the WHO as SARS-CoV2 whereas the disease it induces was entitled as COVID-19, which stands for Coronavirus Disease 2019 [52].
Due to the virus' airborne route of transmission, the possibility to be transmitted ahead of developing symptoms as well as during the disease course [36], the reluctance of governments to institute earlier strict quarantine measures and excessive worldwide people migration it is no wonder that in less than 6 months from its outbreak in Wuhan, official records display more than 6 million of infected people with more than 360.000 deaths along the globe in about 213 countries [49]. The current overall mortality rate is approximatively $6.06 \%$, with wide geographic variations from $0.1 \%$ in Oman and Singapore, 5.9\% in the United States of America, $6.6 \%$ in Romania, $11.3 \%$ in Spain, $14.0 \%$ in United Kingdom, $15.2 \%$ in France, $16.2 \%$ in Belgium up to $24.8 \%$ in Yemen (as reported by "John Hopkins" University Coronavirus Resource Center, accessed on 31 of March 2020) [49]. A higher mortality rate is associated with age, male gender, comorbidities such as obesity, diabetes with a $7.3 \%$ fatality percentage 
[29, 44], cardiovascular diseases (especially hypertension), with a mortality rate of $10.5 \%$, which in contrast to SARS-CoV1, affects the mortality quota more than the presence of chronic obstructive pulmonary disease [44]. Among the listed risk factors are elevated liver enzymes and abnormal kidney function [27, 47]. SARS-CoV2 is known to enter the cell by binding the $\mathrm{S} 1 \mathrm{C}$-terminal domain of spike protein to the angiotensin-converting enzyme 2 receptor (ACE2R) [46]. Regardless of the fact that SARS-CoV2 has a tropism for lungs where it induces interstitial pneumonia [39], due to ACE2R's wide distribution in the human body it can promote microvascular dysfunction [31], myocarditis and many other lesions up to multiple organ failure [13, 39]. Even though it is hard to appreciate the real world expansion of SARS-CoV2 infection and around $80 \%$ of the infected subjects have a mild form of the disease [44], this pandemic has great social, economic, psychologic and even political implications. Therefore, the medical community confronts with an acute urge to identify the best possible curative medicine for the COVID-19 pandemic and because preventative measures failed to restrict its extension and patients need the treatment right at this moment and there is no time to waste, health systems apply to existing drugs with potential antiviral activity. Among such drugs with in vitro and possibly in vivo activity is chloroquine and its derivative hydroxychloroquine [43]. Hydroxychloroquine is favoured due to its reduced toxicity, especially retinal toxicity and higher in vitro potency against SARS-CoV2 in comparison to chloroquine [41].

Unfortunately, there are still no randomized control trials to assess hydroxychloroquine's efficiency against COVID-19 disease, nonetheless the positive results of some small trials induced medical communities to include it in their guidelines. Later on, larger studies presented contradictory results regarding hydroxychloroquine's efficacy as well as safety; therefore, we intended to present the real-world data of the patients who underwent treatment with hydroxychloroquine in our clinic.

\section{Materials and Methods}

Subjects and study design

The study was performed in the period between April and May 2020 and included 32 consecutively admitted patients to the Neurological Clinic of the Colentina Clinical Hospital from Bucharest, Romania (Figure 1). As inclusion criteria served a positive result of the SARS-CoV2 reverse transcription polymerase chain reaction (RT-PCR) test, the specimen being obtained from a nasopharyngeal swab and a concurrent neurological symptomatology. All patients underwent supportive treatment according to their clinical symptomatology in accordance with the local guidelines, the majority receiving enoxaparin due to the pro-coagulant status and recent evidence of coagulation abnormalities induced by SARS-CoV2 infection. Specific treatment for COVID-19 was administered following the recommendations of the infectious diseases team. Informed consent was obtained either from the patients directly or for the subjects unable to give consent an emergency consent was signed by the medical team, followed by a verbal consent of their caregivers. The study was conducted in accordance with the World Medical Association Declaration of Helsinki from 1975 .

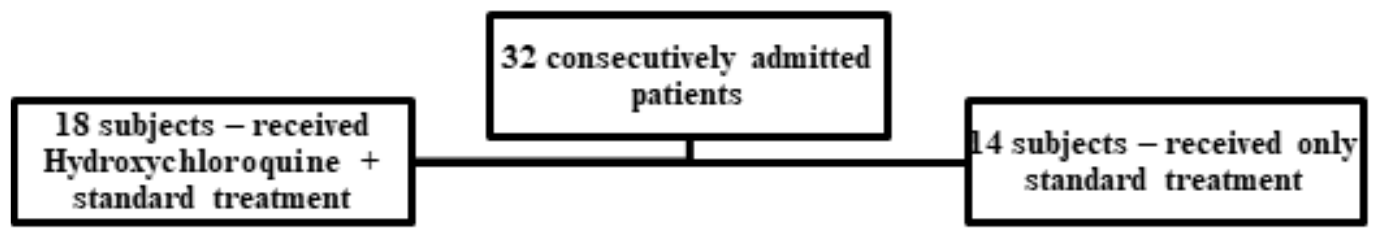

Figure 1.

Study design

\section{Data analysis}

Since we have conducted a retrospective descriptive analysis, the data were extracted from the charts of the patients after they have been discharged. Biostatistical analysis was performed in Microsoft ${ }^{\circledR}$ Excel and a $\mathrm{p}$ value $<0.05$ was considered statistically significant. Primary outcomes were hospitalization duration and the mortality rate. There was made a descriptive analysis as well as regression and correlation of the duration of treatment with hydroxychloroquine and hospitalization period. Another aim was to observe clinical and paraclinical characteristics of the patients and outline whether there were differences in the course of the disease between the patients who received hydroxychloroquine and those who did not, therefore t-Student test was performed. For this purpose, we followed the values of the haemogram, C reactive protein, fibrinogen, ferritin, D-dimers as well as pulmonary computed tomography (CT). It is important to mention that only in isolated cases a secondary pulmonary CT was performed. As regards the paraclinical tests, for laboratory investigations fasting blood was withdrawn by venipuncture in clot activator vacutainer tubes for serum separation. Blood processing was performed in a certified clinical laboratory (GRAL MEDICAL, Bucharest, Romania) in accordance to the manufacturer's 
FARMACIA, 2020, Vol. 68, 4

recommendations in a COBAS 8000 Analyzer for biochemistry and SYSMEX XN 3000 Analyzer for complete blood count. For the detection of SARS-CoV2, the extraction was performed with an automatic extractor and certified and validated CE-IVD Real Time PCR Kits with the CFX 96 Analyzer (GRAL Medical Molecular Biology Laboratory, Bucharest, Romania), respecting the workflow and all necessary conditions with BSL-2 safety level.

The literature review was prepared basing on the articles published in the PubMed database using "Hydroxychloroquine and/or COVID-19" or "Hydroxychloroquine and/or SARS-CoV2" as searching instruments.

\section{Results and Discussion}

The studied group included 32 subjects out of which the majority were females $56.25 \%$ (18/32). The mean age was 55.65 years with values between 21 and 91 , the majority (24 out of 32 subjects) residing in urban areas. Comorbidities were encountered in 24 patients, out of which cardiovascular diseases prevailed, the most frequent being hypertension in 20 patients, followed by ischemic cardiac disease and atrial fibrillation.
Among other concurrent pathologies there were registered diabetes mellitus in 11 patients, dyslipidaemia in 9 patients; chronic kidney disease, heart failure and dementia in 4 patients; epilepsy, multiple sclerosis and asthma in one. It is worth mentioning that 21 patients had $\geq 2$ risk factors for SARS-CoV2 infection such as age, male sex, obesity, hypertension or other cardiovascular disorders and diabetes mellitus. As regards smoking, 6 subjects were active smokers and 4 had been former ones.

The average hospital stay was 11.5 days with a range between 2 and 32 days. Speaking of the COVID-19 disease forms at admission, 14 patients were asymptomatic, 12 had a mild form and 6 subjects had a moderate to severe form. Since it is a neurological clinic, the majority had a concurrent neurological diagnosis at admission, the most prevalent being ischemic stroke followed by headache and peripheral vestibular syndrome, as well as isolated cases of multiple sclerosis relapse, epileptic seizures, sagittal sinus thrombosis.

The results of the biological parameters of the subjects at admission are outlined in the Table I, significant difference was registered only for the $\mathrm{C}$-reactive protein $(\mathrm{CRP})$ values $(\mathrm{p}<0.04)$.

Table I

Paraclinical parameters in subjects with standard therapy and those who were treated with hydroxychloroquine (at admission)

\begin{tabular}{|rcc|}
\hline & Standard therapy =14 & Hydroxychloroquine = 18 \\
\hline $\begin{aligned} \text { Leukocytosis } \\
\text { Mean value }\end{aligned}$ & $4(28.57 \%)$ & $4(22.22 \%)$ \\
Neutrophilia & $7(50 \%)$ & $16 \times 1000 / \mu \mathrm{L}$ \\
Mean value & $8.36 \times 1000 / \mu \mathrm{L}$ & $7(38.88 \%)$ \\
\hline Leukopenia & $0.59 \times 1000 / \mu \mathrm{L}$ \\
Mean value & 0 & $1(5.55 \%)$ \\
Lymphopenia & $4(28.57 \%)$ & $3.35 \times 1000 / \mu \mathrm{L}$ \\
Mean value & $0.92 \times 1000 / \mu \mathrm{L}$ & $12(66.66 \%)$ \\
\hline Thrombocytopenia & $1(7.14 \%)$ & $0.96 \times 1000 / \mu \mathrm{L}$ \\
Mean value & $147 \times 1000 / \mu \mathrm{L}$ & $2(11.11 \%)$ \\
\hline C reactive protein & $4(28.57 \%)$ & $107.5 \times 1000 / \mu \mathrm{L}$ \\
Mean value & $27.11 \mathrm{mg} / \mathrm{L}$ & $11(61.11 \%)$ \\
Fibrinogen & $4(28.57 \%)$ & $76.48 \mathrm{mg} / \mathrm{L}$ \\
Mean value & $492.75 \mathrm{mg} / \mu \mathrm{L}$ & $9(50 \%)$ \\
Ferritin & $2(14.28 \%)$ & $548.33 \mathrm{mg} / \mu \mathrm{L}$ \\
\hline Mean value & $767.2 \mathrm{ng} / \mathrm{mL}$ & $7(38.88 \%)$ \\
\hline Mean value & $2(14.28 \%)$ & $999.02 \mathrm{ng} / \mathrm{mL}$ \\
\hline TGO $-54.95 \mathrm{UL} / \mathrm{L} ;$ & TGO $-92.11 \mathrm{UL} / \mathrm{L} ;$ \\
\hline Mean value & TGP $-57.5 \mathrm{UI} / \mathrm{L}$ & TGP $-201.84 \mathrm{UI} / \mathrm{L}$ \\
\hline Elevated hepatic transaminases & $5(35.71 \%)$ & $12(66.66 \%)$ \\
\hline & $6.36 \mu \mathrm{g} / \mathrm{mL}$ & $4.89 \mu \mathrm{g} / \mathrm{mL}$ \\
\hline
\end{tabular}

Speaking about the pulmonary CT findings, in $37.5 \%$ (12/32) there were detected ground-glass opacities suggestive of COVID-19 pneumonia, out of which in 4 patients the lesions occupied $>75 \%$ of the pulmonary area, in $1>50 \%$ in 2 between 10 and $25 \%$ and in 5 patients the degree was less than $10 \%$. Out of 32 patients, 27 were discharged and there were registered 5 deaths $(15.62 \%)$ in 2 males and 3 females with ages between 53 and 91 years. All of the deceased patients had more than 3 risk associated factors for developing a severe form of COVID-19 disease, such as cardiovascular comorbidities. As regards the symptomatology, 3 patients presented cough associated with dyspnoea and abdominal pain in one patient, thoracic pain in another one and fever in the third one, whereas in another patient the disease started 
with fever and general malaise. With reference to paraclinical investigations, all the deceased patients had significantly elevated inflammatory markers such as the $\mathrm{C}$ reactive protein, ferritin and fibrinogen as well as elevated levels of D-dimers. Speaking of the haemogram, all these patients had neutrophilia at admission, in one also leucocytosis, 4 patients had associated lymphopenia ranging from $680-1240 / \mu \mathrm{L}$ (Normal values: 1500 - 4500/ $\mu \mathrm{L}$ ) and 1 patient had also thrombocytopenia. Moreover, in 3 patients elevated hepatic transaminases were detected, in one the values being suggestive for acute hepatic failure and associated kidney failure was also detected in this particular patient. On pulmonary CT examination, there were registered ground-glass opacity in more than $75 \%$ of the pulmonary area in 2 patients, $10-25 \%$ in one patient, one patient had no pulmonary lesions and in another one the investigation had not been performed.

With reference to hydroxychloroquine administration, we have to mention that 18 patients $(56.25 \%)$ underwent treatment in accordance to our local guideline with a loading dose of 400 b.i.d in the first day, followed by $200 \mathrm{mg}$ b.i.d for a mean duration of 6.5 days, the range being between 2 and 14 days, depending on patient's status. In one patient it was associated with lopinavir/ritonavir 200/50 mg b.i.d, in 3 subjects with azithromycin $500 \mathrm{mg}$ q.d. (quaque die, daily) for an average of 5 days and one patient additionally underwent treatment with tocilizumab for 3 days. In these patients (treated with hydroxychloroquine), with reference to the disease form, 8 were clinically asymptomatic at admission, but had either elevated inflammatory markers, lymphopenia or ground-glass opacities on pulmonary CT detected in one patient. Other 4 patients had a mild form of disease and 6 had a moderate form, more than a half with elevated inflammatory markers and D-dimers, the majority with lymphopenia and in 7 patients were pulmonary CT modifications, namely ground-glass opacity, out of which in one the lesions occupied $>75 \%$ of the pulmonary area and in one $>50 \%$.

In 3 patients, hydroxychloroquine administration had to be stopped earlier than guideline recommendations due to the QTc prolongation in one patient, diarrhoea in another one and abdominal discomfort in the third one. Another important aspect to outline is that all the deceased cases had underwent treatment with hydroxychloroquine, out which 3 had the association with azithromycin.

The average duration of in-hospital stay was almost slightly increased in patients who received treatment with hydroxychloroquine of about 13.7 days (excluding the deceased subjects) and those who did not - 11.3 days. According to the regression analysis, there was observed a positive correlation between the duration of treatment with hydroxychloroquine and the period of hospitalization $(\mathrm{R}=0.59)$ with a p value $<0.001$. This outlines the fact that treatment with hydroxychloroquine did not positively influence viral clearance so as to favour a shorter in-hospital stay (Figure 2).

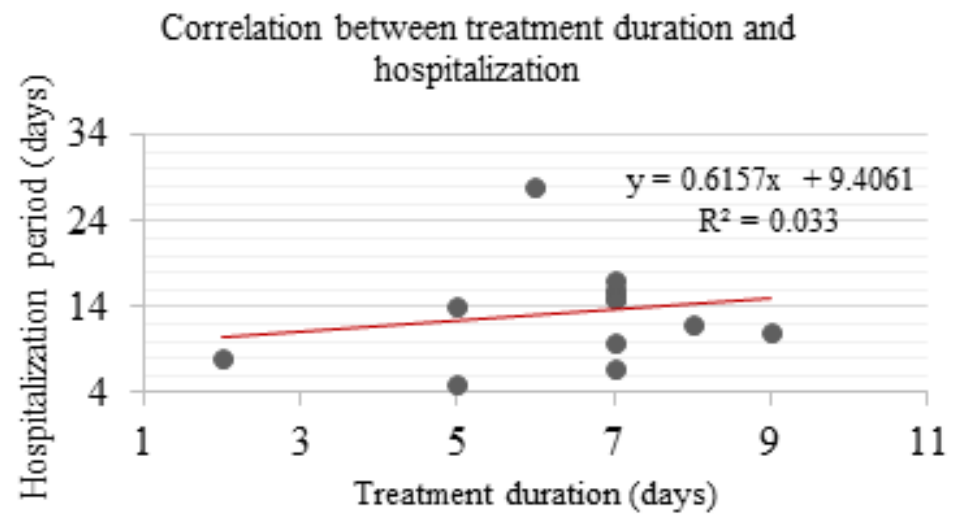

Figure 2.

Correlation between the duration of treatment with hydroxychloroquine and hospitalization

Regarding the influence of the treatment on paraclinical characteristics, we should mention that there were registered no significant modifications between the group of patients who received treatment with hydroxychloroquine and the one without it.

Hydroxychloroquine seems to act as an antiviral drug as well as an immunomodulatory one in COVID-19. Its antiviral action is resumed to halting the glycosylation of ACE2R, thus it diminishes SARS-CoV-2 's spike protein to bind to the ACE2R on host cells and it also rises the $\mathrm{pH}$ of the lysosomes and endosome in such a way preventing virus fusion with the host cells and its consecutive replication. As an immunomodulatory drug it hampers the antigen processing and the presentation of the major histocompatibility complex II (MHC-II)mediated autoantigens to $\mathrm{T}$ cells, thus it decreases T-cell activation and the expression of CD154 as well as of other cytokines (TNF- $\alpha$, IL-1and 6) and by impeding the interaction of cytosolic viral DNA/RNA with TLRs it blocks the transcription of proinflammatory 
genes so decreasing the prospect of a cytokine storm $[6,48]$.

On the other hand, it was also detected that hydroxychloroquine might halt plasmacytoid dendritic cell maturation and inhibit the conversion of perforin to its active state, subsequently diminishing the toxicity of natural killer cells. Due to endosomal $\mathrm{pH}$ alteration, hydroxychloroquine may eventually interfere with the selection of naïve antigen specific B cells, in this way decreasing the affinity maturation of previously involved clones and thus reducing the production of neutralizing antibodies $[22,25]$. It has been also noticed that chloroquine might inhibit $\mathrm{T}$-cell proliferation by diminishing the IL-2 production [14] and responsiveness and since IL-2 appears to have a decisive part in Th-2 cell differentiation [16], which might act via abolishing inflammation in SARS-CoV2 infection, one might speculate that in fact these drugs could have a negative impact on the immune response against the virus [12]. Controversies regarding hydroxychloroquine's safety Regardless of the fact that hydroxychloroquine's safety profile has been extensively studied in patients with autoimmune disease and the overall conclusion is that it is acceptable, its short-term use in patients with COVID-19 disease spurs conflicting observations regarding hydroxychloroquine's safety.

Hydroxychloroquine has an extended plasma elimination half-life of about 900 - 1300 hours related to its large distribution volume and broad tissue uptake [7], thus leading to accumulation with prolonged and chronic use [35]. The risk of adverse effects increases after cumulative doses exceed $2.3 \mathrm{mg} / \mathrm{kg}$ of body weight/day [20]. Short-term administration in COVID-19 patients should pose less danger, but in these patients are used much higher doses. Therefore, it was established that the optimal effective and safe dose for such patients would be a loading dose of $400 \mathrm{mg}$ b.i.d (bis in die, twice daily) in the first day followed by $200 \mathrm{mg}$ b.i.d for about 4 days [41].

Among the most frequently reported adverse effects are retinal afflictions usually preceded by ocular pruritus, leading sometimes to irreversible retinopathy due to hydroxychloroquine's affinity for melanin molecules inducing lesions on macular cones [38, 40], as well as photosensitivity, skin discoloration and it even might exacerbate psoriasis [17]. Other serious reported side effects are ototoxicity [30], toxic epidermal necrolysis [24], hepatic failure [19], cardiotoxicity and neuromyopathy [33] by vacuolization of the cardiac and skeletal muscle cells after it inhibits lysosomal phospholipases' action [42] as well as gastrointestinal implications, usually milder forms like diarrhoea, especially when given on an empty stomach. Regarding laboratory modifications, there were reported hypoglycaemia, elevated hepatic transaminases, rarely leukopenia, anaemia or thrombocytopenia [17]. Even death was reported in Nigeria among patients selftreated with overdoses of chloroquine for SARS-CoV2 infection [50], as well as 16 deaths out of 41 patients in a randomized, double-blinded Brazilian study who were given chloroquine $600 \mathrm{mg}$ b.i.d for 10 days combined with ceftriaxone and azithromycin, mostly related to ventricular tachycardia [2].

As regards the cardiotoxicity, most prominent is the QTc prolongation reported in up to $93 \%$ of the subjects who underwent treatment with hydroxychloroquine alone or in combination with azithromycin in one study [1] and in $20 \%$ in another one [21]. There was also reported that hydroxychloroquine might increase the risk of angina up to $20 \%$ as well as that of heart failure when used for a short period [15]. With reference to interactions, apart from increasing the risk of cardiac arrhythmias, hydroxychloroquine might reduce antibiotics (ampicillin) and immunosuppressants' (cyclosporine) activity, as well as increase the risk of convulsions in combination with mefloquine [20].

Several trials have been launched since the pandemic's outbreak to assess hydroxychloroquine's efficacy in COVID-19 disease implying not only its in vivo antiviral activity but also its low cost and chronic widespread use as a treatment for autoimmune diseases such as rheumatoid arthritis, systemic lupus erythematosus, juvenile idiopathic arthritis and Sjogren's syndrome as well as in parasitic disorders like malaria and amebiasis [35].

In an interim analysis, a Chinese group reported that there was noticed faster viral shedding conversion, improved pneumonia features along with lung imaging and a reduced disease duration in patients who underwent treatment with chloroquine, without major adverse effects [8]. Subsequently an expert consensus in China came out with a proposal to include this drug at a dose of $500 \mathrm{mg}$ b.i.d for 10 days in the treatment regimen of patients with COVID-19 disease [45].

Following this study, a small French open-label nonrandomized clinical trial, that appeared showing important viral load reduction and mentioned that the effect seems to be reinforced by azithromycin [9]. However, it was extensively criticized which even led to the publishing journal's society to make a declaration that it did "not meet the Society's expected standards" [37]. Nevertheless the same group made another uncontrolled, non-comparative observational study, involving 80 patients with a mild form of COVID-19 disease, who underwent treatment with hydroxychloroquine (600 $\mathrm{mg} /$ day for 10 days) and azithromycin for at least 3 days, in which it was observed a $83 \%$ of negative nasopharyngeal viral load at day 7 and $93 \%$ at day 8 and the patients had a mean length of stay of about 5 days in hospital [10].

Apart from studies that claim a positive action of the combination between hydroxychloroquine with azithromycin against SARS-COV-2 infection, there is an article that proposes a possible beneficial combination of hydroxychloroquine with ivermectin [26], which was established to have an in vitro antiviral action 
against SARS-CoV2, a single dose being capable to handle viral replication for up to 24 - 48 hours [3]. Furthermore, in another Chinese study that included 62 patients of which 31 were controls, treated with $400 \mathrm{mg}$ of hydroxychloroquine for 5 days, it was remarked that the treated patients demonstrated a remarkable reduced fever, cough remission time as well as a greater percentage of pneumonia improvement on computed tomographic (CT) scans [4].

Such limited observational studies had a significant influence worldwide, which led to it being included in many countries' guidelines and even made medical institutions to issue special emergency authorization like the one issued by the end of March 2020 in the United States of America [51]. On the other hand, later on started to appear trials that claimed contradictory results regarding hydroxychloroquine's efficacy in the fight against SARS-CoV2 infection.

Shortly after the first French study showing a substantial viral load reduction in patients using hydroxychloroquine, another group tried to reproduce their results on a smaller number of patients - 11 consecutive subjects who received the similar dosing regimen, but they observed that 8 patients were still positive at days 5 and 6 following treatment initiation and in one patient hydroxychloroquine had to be stopped earlier due to QTc prolongation [23]. In another prospective pilot study with a sample of 30 patients, half of which were controls and the other half receiving treatment with hydroxychloroquine, there was observed a negative viral load by day 7 in $86.7 \%$ of the treated group and $93.3 \%$ of the control one [5].

Further, on emerged studies with larger samples, such as a Chinese multicentre, open label, randomized controlled trial with a group of 150 patients, the majority with mild to moderate forms of the disease which assessed the probability of negative viral conversion up to 28 days and demonstrated a similar rate between the treated and the control group. It also displayed a higher rate of adverse events in the arm with hydroxychloroquine, about $30 \%$ mostly of which was diarrhoea [34].

In a study involving 181 patients from 4 French hospitals with documented COVID-19 pneumonia that underwent $\geq 2 \mathrm{~L} / \mathrm{min}$ of oxygen therapy, out of which 84 received hydroxychloroquine $600 \mathrm{mg} /$ day, the primary endpoint being the transfer to intensive care unit within 7 days or death, it was stated that the results did not demonstrate a significant difference between the 2 groups [18]. Moreover, in a metaanalysis of 3 studies with a total of 210 involved subjects on viral clearance, the use of hydroxychloroquine demonstrated no benefit whereas a meta-analysis of other 3 studies concerning 474 patients established a substantial raise in mortality for subjects using the drug, compared to controls [32].

Similar conclusions appeared from larger trials, like an observational study including a considerable sample of 1446 consecutive admitted patients at a large centre in New York, of which 58.9\% received treatment with hydroxychloroquine and were more severely-ill from the start, there was identified no important association between treatment with hydroxychloroquine and intubation or death [11]. In addition came a retrospective multicentre cohort study involving 1438 patients also from New York, of which $70 \%$ of subjects underwent treatment with hydroxychloroquine alone or in association with azithromycin, in which it was observed no major divergence in in-hospital fatality between patients who received the above mentioned drugs and those who did not, after adjustment for concurrent illnesses and disease severity on admission [28].

Moreover, the results of our descriptive retrospective study delineate the fact that administration of hydroxycholoroquine in patients diagnosed with SARS-CoV2 infection does not reduce the hospitalization period, there being attested a positive correlation $(\mathrm{R}=0.59)$. In our sample although small, it was observed a shorter duration of in-hospital for patients who did not receive hydroxychloroquine in comparison to those who did. Furthermore, there was determined no improvement with reference to biological parameters in patients receiving hydroxychloroquine versus those who did not administer it. The limitations of the study reside in its small sample as well as the fact that it was not randomized, and it was retrospective.

Therefore, in line with the results of the abovementioned more recent trials with a much larger sample $[11,18,28,32,34]$ we have remarked no significant influence in our analysis on patient's outcome such as duration of the in-hospital stay and fatality rate, in those who underwent treatment with hydroxychloroquine. It goes without saying that in order to make an accurate assumption regarding this drug's efficacy and especially safety, we need randomized, double-blind controlled studies conducted on a sample with statistically significant size. However, when confronted with a crisis of such amplitude, it is our duty to try and find the best solution with the little we have at the moment.

\section{Conclusions}

The current SARS-CoV2 pandemic introduced major alterations in every aspect of our life and activity. In consequence, in the current era of evidence-based medicine we confront with a crisis of using off-label drugs in order to offer the best of care with the risk of doing more harm than the potential benefit of these drugs. Present studies display contradictory results with reference to hydroxychloroquine's activity opposing COVD-19 disease, though there is a greater tendency to outline its lack of efficacy as it was observed in our analysis as well and higher risk of inducing adverse effects. Along these lines, as it is recommended in other studies, until clear-cut evidence emerges, this drug should be given only by thoroughly balancing 
the risk and benefit in controlled trials and not on a large scale.

\section{Conflict of interest}

The authors declare no conflict of interest.

\section{References}

1. Bessière $\mathrm{F}$, Roccia $\mathrm{H}$, Delinière $\mathrm{A}$, Charrière $\mathrm{R}$, Chevalier P, Argaud L, Cour M, Assessment of QT intervals in a case series of patients with coronavirus disease 2019 (covid-19) infection treated with hydroxychloroquine alone or in combination with azithromycin in an intensive care unit. JAMA Cardiol., 2020: e201787, doi: 10.1001/jamacardio.2020.1787.

2. Borba MGS, Val FFA, Sampaio VS, Alexandre MAA, Melo GC, Brito M, Mourão MPG, Brito-Sousa JD, Baía-da-Silva D, Guerra MVF, Hajjar LA, Pinto RC, Balieiro AAS, Pacheco AGF, Santos JDO Jr, Naveca FG, Xavier MS, Siqueira AM, Schwarzbold A, Croda J, Nogueira ML, Romero GAS, Bassat Q, Fontes CJ, Albuquerque BC, Daniel-Ribeiro CT, Monteiro WM, Lacerda MVG; CloroCovid-19 Team, Effect of high $v s$ low doses of chloroquine diphosphate as adjunctive therapy for patients hospitalized with severe acute respiratory syndrome coronavirus 2 (SARS-CoV-2) infection: A randomized clinical trial. JAMA Netw Open, 2020; 3(4): 1-14

3. Caly L, Druce JD, Catton MG, Jans DA, Wagstaff $\mathrm{KM}$, The FDA-approved drug ivermectin inhibits the replication of SARS-CoV-2 in vitro. Antiviral Res., 2020; 178: 104787, doi: 10.1016/j.antiviral.2020.104787.

4. Catrinoiu D, Ceriello A, Rizzo M, Serafinceanu C, Montano N, Pantea Stoian A, Udeanu DI, Jinga V, Iorgulescu G, Dumitrescu IB, Diabetes and reninangiotensin-aldosterone system: implications for COVID19 patients with diabetes treatment management. Farmacia, 2020; 68(3): 377-383.

5. Chen J, Liu D, Liu L, Liu P, Xu Q, Xia L, Ling Y, Huang D, Song S, Zhang D, Qian Z, Li T, Shen Y, $\mathrm{Lu} \mathrm{H}$, A pilot study of hydroxychloroquine in treatment of patients with moderate COVID-19. Zhejiang Da Хие Хие Bao Yi Xие Ban, 2020; 49(2): 215-219, (available in Chinese)

6. Devaux CA, Rolain JM, Colson P, Raoult D, New insights on the antiviral effects of chloroquine against coronavirus: what to expect for COVID-19?. Int $J$ Antimicrob Agents, 2020; 55(5): 105938. doi: 10.1016/j.ijantimicag.2020.105938.

7. Ducharme J, Farinotti R, Clinical pharmacokinetics and metabolism of chloroquine. Focus on recent advancements. Clin Pharmacokinet., 1996; 31(4): 257-274

8. Gao J, Tian Z, Yang X, Breakthrough: Chloroquine phosphate has shown apparent efficacy in treatment of COVID-19 associated pneumonia in clinical studies. Biosci Trends., 2020; 14(1): 72-73.

9. Gautret P, Lagier JC, Parola P, Hoang VT, Meddeb L, Mailhe M, Doudier B, Courjon J, Giordanengo V, Vieira VE, Tissot Dupont H, Honoré S, Colson P, Chabrière E, La Scola B, Rolain JM, Brouqui P, Raoult D, Hydroxychloroquine and azithromycin as a treatment of COVID-19: results of an open-label non-randomized clinical trial. Int J Antimicrob Agents., 2020; 56(1): 105949, doi: 10.1016/j.jjantimicag.2020.105949.

10. Gautret P, Lagier JC, Parola P, Hoang VT, Meddeb L, Sevestre J, Mailhe M, Doudier B, Aubry C, Amrane S, Seng P, Hocquart M, Eldin C, Finance J, Vieira VE, Tissot-Dupont HT, Honoré S, Stein A, Million M, Colson P, La Scola B, Veit V, Jacquier A, Deharo JC, Drancourt M, Fournier PE, Rolain JM, Brouqui P, Raoult D, Clinical and microbiological effect of a combination of hydroxychloroquine and azithromycin in 80 COVID-19 patients with at least a six-day follow up: A pilot observational study. Travel Med Infect Dis., 2020; 34: 101663, doi: 10.1016/j.tmaid.2020.101663.

11. Geleris J, Sun Y, Platt J, Zucker J, Baldwin M, Hripcsak G, Labella A, Manson DK, Kubin C, Barr RG, Sobieszczyk ME, Schluger NW, Observational study of hydroxychloroquine in hospitalized patients with Covid-19. N Engl J Med., 2020; 382(25): 24112418.

12. Guastalegname M, Vallone A, Could chloroquine /hydroxychloroquine be harmful in Coronavirus Disease 2019 (COVID-19) treatment?. Clin Infect Dis., 2020: ciaa321, doi: 10.1093/cid/ciaa321.

13. Huang C, Wang Y, Li X, Ren L, Zhao J, Hu Y, Zhang L, Fan G, Xu J, Gu X, Cheng Z, Yu T, Xia J, Wei Y, Wu W, Xie X, Yin W, Li H, Liu M, Xiao Y, Gao H, Guo L, Xie J, Wang G, Jiang R, Gao Z, Jin Q, Wang $\mathrm{J}$, Cao B, Clinical features of patients infected with 2019 novel coronavirus in Wuhan, China. Lancet, 2020; 395(10223): 497-506.

14. Landewé RB, Miltenburg AM, Verdonk MJ, Verweij CL, Breedveld FC, Daha MR, Dijkmans BA, Chloroquine inhibits $\mathrm{T}$ cell proliferation by interfering with IL-2 production and responsiveness. Clin Exp Immunol., 1995; 102(1): 144-151.

15. Lee TC, MacKenzie LJ, McDonald EG, Tong SYC, An observational cohort study of hydroxychloroquine and azithromycin for COVID-19: (Can't Get No) Satisfaction. Int J Infect Dis., 2020; 98: 216-217.

16. Liao W, Schones DE, Oh J, Cui Y, Cui K, Roh TY, Zhao K, Leonard WJ, Priming for T helper type 2 differentiation by interleukin 2-mediated induction of interleukin 4 receptor alpha-chain expression. Nat Immunol., 2008; 9(11): 1288-1296.

17. Littlejohn E, Hydroxychloroquine use in the COVID19 patient. Cleve Clin J Med., 2020: 1-4, doi: 10.3949/ccjm.87a.ccc011.

18. Mahévas M, Tran VT, Roumier M, Chabrol A, Paule R, Guillaud C, Fois E, Lepeule R, Szwebel TA, Lescure FX, Schlemmer F, Matignon M, Khellaf M, Crickx E, Terrier B, Morbieu C, Legendre P, Dang J, Schoindre Y, Pawlotsky JM, Michel M, Perrodeau E, Carlier N, Roche N, de Lastours V, Ourghanlian C, Kerneis S, Ménager P, Mouthon L, Audureau E, Ravaud P, Godeau $\mathrm{B}$, Gallien S, Costedoat-Chalumeau N, Clinical efficacy of hydroxychloroquine in patients with COVID-19 pneumonia who require oxygen: observational comparative study using routine care data. BMJ, 2020; 369: $\mathrm{m} 1844$, doi: 10.1136/bmj.m1844, Erratum in: BMJ, 2020; 369: $\mathrm{m} 2328$

19. Makin AJ, Wendon J, Fitt S, Portmann BC, Fulminant hepatic failure secondary to hydroxychloroquine. Gut, 1994; 35(4): 569-570. 
FARMACIA, 2020, Vol. 68, 4

20. Marmor MF, Carr RE, Easterbrook M, Farjo AA, Mieler WF; American Academy of Ophthalmology, Recommendations on screening for chloroquine and hydroxychloroquine retinopathy: a report by the American Academy of Ophthalmology. Ophthalmology, 2002; 109(7): 1377-1382.

21. Mercuro NJ, Yen CF, Shim DJ, Maher TR, McCoy CM, Zimetbaum PJ, Gold HS, Risk of QT Interval Prolongation Associated With Use of Hydroxychloroquine With or Without Concomitant Azithromycin Among Hospitalized Patients Testing Positive for Coronavirus Disease 2019 (COVID-19). JAMA Cardiol., 2020: e201834, doi: 10.1001/jamacardio.2020.1834.

22. Mohammad FS, Karmakar V, Irfan Z, Hydroxychloroquine and azithromycin combination could be lethal to COVID-19 patients. Farmacia, 2020; 68(3): 384-389.

23. Molina JM, Delaugerre C, Le Goff J, Mela-Lima B, Ponscarme D, Goldwirt L, de Castro N, No evidence of rapid antiviral clearance or clinical benefit with the combination of hydroxychloroquine and azithromycin in patients with severe COVID-19 infection. Med Mal Infect., 2020; 50(4): 384, doi: 10.1016/j.medmal.2020.03.006.

24. Murphy M, Carmichael AJ, Fatal toxic epidermal necrolysis associated with hydroxychloroquine. Clin Exp Dermatol., 2001; 26(5): 457-458, Erratum in: Clin Exp Dermatol., 2001; 26(6): 560.

25. Murugan R, Buchauer L, Triller G, Kreschel C, Costa G, Pidelaserra Martí G, Imkeller K, Busse CE, Chakravarty S, Sim BKL, Hoffman SL, Levashina EA, Kremsner PG, Mordmüller B, Höfer T, Wardemann $\mathrm{H}$, Clonal selection drives protective memory B cell responses in controlled human malaria infection. Sci Immunol., 2018; 3(20): 1-11.

26. Patrì A, Fabbrocini G, Hydroxychloroquine and ivermectin: A synergistic combination for COVID-19 chemoprophylaxis and treatment? J Am Acad Dermatol., 2020; 82(6): e221, doi: 10.1016/j.jaad.2020.04.017.

27. Richardson S, Hirsch JS, Narasimhan M, Crawford JM, McGinn T, Davidson KW; and the Northwell COVID-19 Research Consortium, Barnaby DP, Becker LB, Chelico JD, Cohen SL, Cookingham J, Coppa K, Diefenbach MA, Dominello AJ, Duer-Hefele J, Falzon L, Gitlin J, Hajizadeh N, Harvin TG, Hirschwerk DA, Kim EJ, Kozel ZM, Marrast LM, Mogavero JN, Osorio GA, Qiu M, Zanos TP, Presenting characteristics, comorbidities, and outcomes among 5700 patients hospitalized with COVID-19 in the New York City area. JAMA, 2020; 323(20): 2052-2059, doi: 10.1001/ jama.2020.6775, Erratum in: doi: 10.1001/jama.2020.7681.

28. Rosenberg ES, Dufort EM, Udo T, Wilberschied LA, Kumar J, Tesoriero J, Weinberg P, Kirkwood J, Muse A, DeHovitz J, Blog DS, Hutton B, Holtgrave DR, Association of treatment with hydroxychloroquine or azithromycin with in-hospital mortality in patients with COVID-19 in New York state. JAMA, 2020; 323(24): 2493-2502.

29. Ruan S, Likelihood of survival of coronavirus disease 2019. Lancet Infect Dis., 2020; 20(6): 630-631.

30. Seçkin U, Ozoran K, Ikinciogullari A, Borman P, Bostan EE, Hydroxychloroquine ototoxicity in a patient with rheumatoid arthritis. Rheumatol Int., 2000; 19(5): 203-204.

31. Shi S, Qin M, Shen B, Cai Y, Liu T, Yang F, Gong W, Liu X, Liang J, Zhao Q, Huang H, Yang B, Huang
C, Association of cardiac injury with mortality in hospitalized patients with COVID-19 in Wuhan, China. JAMA Cardiol., 2020; 5(7): 802-810.

32. Singh AK, Singh A, Singh R, Misra A, Hydroxychloroquine in patients with COVID-19: A Systematic Review and meta-analysis. Diabetes Metab Syndr., 2020; 14(4): 589-596.

33. Stein M, Bell MJ, Ang LC, Hydroxychloroquine neuromyotoxicity. J Rheumatol., 2000; 27(12): 29272931.

34. Tang W, Cao Z, Han M, Wang Z, Chen J, Sun W, Wu Y, Xiao W, Liu S, Chen E, Chen W, Wang X, Yang J, Lin J, Zhao Q, Yan Y, Xie Z, Li D, Yang Y, Liu L, Qu J, Ning G, Shi G, Xie Q, Hydroxychloroquine in patients with mainly mild to moderate coronavirus disease 2019: open label, randomised controlled trial. BMJ, 2020; 369: m1849, doi: 10.1136/bmj.m1849.

35. Trichonas TJSG, Chloroquine and hydroxychloroquine toxicity. Stat Pearls Publishing LLC, 2019.

36. van Doremalen N, Bushmaker T, Morris DH, Holbrook MG, Gamble A, Williamson BN, Tamin A, Harcourt JL, Thornburg NJ, Gerber SI, Lloyd-Smith JO, de Wit E, Munster VJ, Aerosol and surface stability of SARS-CoV-2 as compared with SARS-CoV-1. N Engl J Med., 2020; 382(16): 1564-1567.

37. Voss A, Official statement from International Society of Antimicrobial Chemotherapy (ISAC), www.isac.world.

38. Wolfe F, Marmor MF, Rates and predictors of hydroxychloroquine retinal toxicity in patients with rheumatoid arthritis and systemic lupus erythematosus. Arthritis Care Res (Hoboken), 2010; 62(6): 775-784.

39. Xu Z, Shi L, Wang Y, Zhang J, Huang L, Zhang C, Liu S, Zhao P, Liu H, Zhu L, Tai Y, Bai C, Gao T, Song J, Xia P, Dong J, Zhao J, Wang FS, Pathological findings of COVID-19 associated with acute respiratory distress syndrome. Lancet Respir Med., 2020; 8(4): 420-422.

40. Yam JC, Kwok AK, Ocular toxicity of hydroxychloroquine. Hong Kong Med J., 2006; 12(4): 294-304.

41. Yao X, Ye F, Zhang M, Cui C, Huang B, Niu P, Liu X, Zhao L, Dong E, Song C, Zhan S, Lu R, Li H, Tan $\mathrm{W}$, Liu D. In vitro antiviral activity and projection of optimized dosing design of hydroxychloroquine for the treatment of severe acute respiratory syndrome coronavirus 2 (SARS-CoV-2). Clin Infect Dis., 2020: ciaa237, doi: 10.1093/cid/ciaa237.

42. Yogasundaram H, Putko BN, Tien J, Paterson DI, Cujec B, Ringrose J, Oudit GY, Hydroxychloroquineinduced cardiomyopathy: case report, pathophysiology, diagnosis, and treatment. Can J Cardiol., 2014; 30(12): 1706-1715.

43. Zhang C, Huang S, Zheng F, Dai Y, Controversial treatments: An updated understanding of the coronavirus disease 2019. J Med Virol., 2020: doi: 10.1002/jmv.25788.

44. Epidemiology Working Group for NCIP Epidemic Response, Chinese Center for Disease Control and Prevention, [The epidemiological characteristics of an outbreak of 2019 novel coronavirus diseases (COVID-19) in China]. Zhonghua Liu Xing Bing Xue Za Zhi, 2020; 41(2): 145-151, (available in Chinese).

45. Multicenter collaboration group of Department of Science and Technology of Guangdong Province and Health Commission of Guangdong Province for chloroquine in the treatment of novel coronavirus pneumonia. 
[Expert consensus on chloroquine phosphate for the treatment of novel coronavirus pneumonia]. Zhonghua Jie He He Hu Xi Za Zhi, 2020; 43(3): 185-188, (available in Chinese).

46. Zhou P, Yang XL, Wang XG, Hu B, Zhang L, Zhang W, Si HR, Zhu Y, Li B, Huang CL, Chen HD, Chen J, Luo Y, Guo H, Jiang RD, Liu MQ, Chen Y, Shen XR, Wang X, Zheng XS, Zhao K, Chen QJ, Deng F, Liu LL, Yan B, Zhan FX, Wang YY, Xiao GF, Shi ZL, A pneumonia outbreak associated with a new coronavirus of probable bat origin. Nature, 2020; 579(7798): 270-273.

47. Zhou F, Yu T, Du R, Fan G, Liu Y, Liu Z, Xiang J, Wang Y, Song B, Gu X, Guan L, Wei Y, Li H, Wu X, Xu J, Tu S, Zhang Y, Chen H, Cao B, Clinical course and risk factors for mortality of adult inpatients with COVID-19 in Wuhan, China: a retrospective cohort study. Lancet, 2020; 395(10229): 1054-1062, Erratum in: Lancet, 2020; 395(10229): 1038.

48. Zhou D, Dai SM, Tong Q, COVID-19: a recommendation to examine the effect of hydroxychloroquine in preventing infection and progression. J Antimicrob Chemother., 2020; 75(7): 1667-1670.

49. https://coronavirus.jhu.edu.

50. York G, Nigerians poisoned after taking doses of drug praised by Trump. The Globe and Mail, www.theglobeandmail.com.

51. US Food and Drug Administration. Emergency Use Authorization. Hydroxychloroquine sulfate health care provider fact sheet, www.fda.gov.

52. World Health Organization. Director-General's remarks at the media briefing on 2019-nCoV on 11 February 2020, www.who.int 